\title{
Quantitative and qualitative carcass characteristics of feedlot ewes subjected to increasing levels of concentrate in the diet
}

\author{
[Características quantitativas e qualitativas da carcaça de borregas confinadas submetidas a \\ níveis crescentes de concentrado na dieta] \\ R.A.S. Cacere $^{1}$, M.G. Morais $^{1}$, F.V. Alves ${ }^{2}$, G.L.D. Feijón ${ }^{2}$, C.C.B.F. Ítavo ${ }^{1}$, \\ L.C.V. Ítavo ${ }^{3}$, L.B. Oliveira ${ }^{1}$, C.B. Ribeiro ${ }^{1}$ \\ ${ }^{1}$ Faculdade de Medicina Veterinária e Zootecnia - Universidade Federal de Mato \\ Grosso do Sul - FAMEZ-UFMS - Campo Grande, MS \\ ${ }^{2}$ Embrapa Gado de Corte - CNPGC - Campo Grande, MS \\ ${ }^{3}$ Universidade Católica Dom Bosco (UCDB) - Campo Grande, MS
}

\begin{abstract}
The aim of this study was to evaluate the effect of increasing levels of concentrate on the quantitative and qualitative carcass characteristics of feedlot ewes. Twenty-four crossbred ewes were randomly distributed in four treatments: (1) diet with 20\%; (2) 40\%; (3) 60\%; and (4) $80 \%$ of concentrate. Animals were slaughtered when those receiving the diet with $80 \%$ of concentrate reached adult weight, at around $50 \mathrm{~kg}$ LW. The data were analyzed by means of variance and regression analyses and correlations. The levels of concentrate increased live weight at slaughter linearly. Height at the withers and rump presented medium to high correlation (0.86). The correlation of loin eye area measured on the carcass and by ultrasound examination was 0.81 , whereas for back fat thickness it was 0.85 . The increase in the use of concentrate in the diets promotes heavier carcasses with better yields and fat cover. Some measures obtained in vivo presented high correlation with those measured on the carcass. The use of ultrasound can be a way to predict the in vivo loin eye area. The use of concentrate improves the meat quality in variables' color and appearance.
\end{abstract}

Keywords: carcass yield, color, meat quality

\section{RESUMO}

Objetivou-se avaliar o efeito de níveis crescentes de concentrado sobre as características quantitativas e qualitativas de carcaça de borregas confinadas. Vinte e quatro borregas mestiças foram aleatoriamente distribuídas em quatro tratamentos: (1) dieta com 20\%; (2) 40\%; (3) 60\% e (4) 80\% de concentrado. Os animais foram abatidos quando os que recebiam a dieta $80 \%$ de concentrado atingiram o peso adulto, ao redor de $50 \mathrm{~kg} \mathrm{PV}$. Os dados foram analisados por meio de análise de variância e regressão e de correlações. Os níveis de concentrado aumentaram linearmente o peso vivo ao abate. A altura de cernelha e de garupa apresentaram correlação média a alta $(0,86)$. A correlação da área de olho de lombo medida na carcaça e por meio de ultrassom apresentou valor de 0,81, enquanto a espessura de gordura subcutânea foi de 0,85. O aumento do uso de concentrado nas dietas proporciona carcaças pesadas e com melhores rendimentos e acabamentos. Algumas medidas feitas in vivo apresentaram alta correlação com as medidas na carcaça. $O$ uso do ultrassom pode ser utilizado como forma de predição da área de olho de lombo in vivo. $O$ uso do concentrado melhora a qualidade da carne nos parâmetros de cor e aparência.

Palavras-chave: cor, qualidade de carne, rendimento de carcaça

Recebido em 31 de outubro de 2012

Aceito em 11 de fevereiro de 2014

E-mail: rafaele.alcantara@agricultura.gov.br 


\section{INTRODUCTION}

In sheep rearing, diets usually supplied to feedlot animals are composed of varying levels of concentrate and roughage. Thus, studies that evaluate the roughage:concentrate ratios in the diet are important for the establishment of the most appropriate nutritional plan for the production system. However, such data are almost inexistent in the scientific literature, especially on females, which present great importance in the current productive scenario (Pinheiro et al., 2009).

One of the most marked characteristics in the carcass of females is the fact that they have physiological maturity early when compared with castrated males (intermediate) and intact males (late), resulting in a greater level of apparent fat (Cardoso, 2008).

Therefore, feeding strategies for finishing, coupled with in vivo evaluations that correlate with those of carcass to predict animal performance, can provide information capable of aiding in the definition of the best moment for slaughter.

However, most of the measures that present good correlation with the carcass composition are obtained directly on the carcass, requiring the slaughter of the animal and lots of time, in addition to being costly. Thus, indirect methods for the evaluation of carcass, such as ultrasound, have been studied, once they enable a quick, non-invasive evaluation (Yokoo et al., 2009), with good accuracy of the body composition (McManus et al., 2013).

In addition to the quantitative characteristics, one should take into account the qualitative characteristics of the meat, such as texture, taste, appearance and odor.

In this context, the aim was to evaluate the effect of increasing levels of concentrate on the quantitative and qualitative carcass characteristics of feedlot ewes.

\section{MATERIAL AND METHODS}

An experiment was conducted in the Faculty of Veterinary Medicine and Animal Science of Universidade Federal do Mato Grosso do Sul, in
Campo Grande, MS, Brazil, from July to December 2009. Twenty-four newly weaned crossbred ewes were used. Animals were of approximately 2 months of age, originated from the crossing with wool animals (crossings of Texel, Ile de France and animals of undefined breed (UDB)) with initial average live weight of $18 \mathrm{~kg}$, and treated against endoparasites.

The design adopted was completely randomized, with six ewes per treatment. The animals were placed in individual stalls provided with trough for roughage and concentrate, drinker, and trough for mineral supplement. Ewes were distributed in four groups receiving increasing levels of concentrate: (1) diet with 20\%; (2) diet with $40 \%$; (3) diet with $60 \%$; and (4) diet with $80 \%$ concentrate. All the animals received feed ad libitum, supplied twice daily, according to the individual live weight. The control of intake was performed daily.

Diets were formulated according to the National... (2007), so that the daily weights would vary from 100 to $250 \mathrm{~g} /$ day, according to the increasing levels of concentrate. One single concentrate was used in all the treatments, containing $21.46 \%$ crude protein (CP) and $78.19 \%$ total digestible nutrients (TDN), based on corn and soybean meal and shredded Tifton 85 hay (Cynodon spp.), containing $9.81 \% \mathrm{CP}$ and $54.58 \%$ TDN, as roughage. Variable amounts of urea were added in the diets of $20 \%$ to $60 \%$ concentrate so that they would present increasing levels of protein and energy. Diets presented $13.34 ; 16.32 ; 19.33$ and $22.37 \% \mathrm{CP}$ and 60.10 ; $68.91 ; 74.40$ and $76.73 \%$ TDN for the levels of 20, 40, 60 and $80 \%$ concentrate, respectively. Water and mineral supplement were available permanently. The feedlot period was of approximately 120 days, and in this period, animals were weighed at 14-day intervals.

All the animals were slaughtered when those receiving the diet with highest percentage of concentrate $(80 \%)$ reached adult weight, at around $50 \mathrm{~kg}$ live weight (LW). The slaughter of animals was done in the Laboratory of Carcasses of Embrapa Gado de Corte in Campo Grande, MS, Brazil

Ewes were fasted of solids for 18 hours before slaughter, and then weighed for the obtainment of live weight at slaughter (LWS). The 
determination of the percentage of fasting loss was achieved through the formula (FL) $(\%)=$ [(LW - LWS $) / L W S] \times 100$.

Moments before the stunning, in vivo body measurements were obtained: height at the withers (HW) vertical distance between the highest point of the withers and the ground, in $\mathrm{cm}$, with the animal kept in the correct position of limbs; height at the rump (HR): vertical measurement between the midpoint of the ileum to the ground, in $\mathrm{cm}$; and body length (BL), distance between the base of the tail until the base of the neck, in $\mathrm{cm}$. All measures were obtained with fiber glass measuring tape graduated in centimeters.

Prior to measuring the loin eye area and back fat thickness by ultrasound (PIEMEDICAL device model Áquila VET, with linear transducer of 6.0/8.0 MHz frequency and $7 \mathrm{~cm}$ length), animals had their hair removed, were cleaned and had gel applied on them for perfect engagement of the transducer between the 12th and 13th ribs on their right side; the ultrasound transducer was placed perpendicular to the muscle Longissimus dorsi.

Subsequently, ewes were stunned by brain concussion (with a captive bolt pistol), followed by section of the carotid artery and jugular vein. All the blood was collected and weighed in buckets previously tared and identified. Head, paws and genitals were skinned, eviscerated and removed for determination of warm carcass weight (WCW), and empty body weight (EBW) was determined by LWS minus the content of the gastrointestinal tract, gallbladder and bladder. Warm carcass yield (WCY) was obtained by the formula WCY $(\%)=($ WCW/LWS $) \times 100$. The true or biological yield (TY) was obtained by the formula TY $(\%)=($ WCW/EBW $) \times 100$. Carcasses were taken to a cold chamber at a temperature of $\pm 4^{\circ} \mathrm{C}$, for a period of 24 hours, and subsequently weighed for obtainment of cold carcass weight $(\mathrm{CCW})$. The percentage of cooling loss (CL), in which CL $(\%)=(\mathrm{WCW}-$ CCW) $x$ 100/WCW, and the cold carcass yield (CCY), represented by the ratio between CCW and LWS, also expressed in percentage, were calculated.

Carcasses were split in half, and half-carcasses were weighed. Linear mensurations were performed on the left half-carcass, length of the leg (LL), obtained by the distance from the perimeter and the front edge of the tarsometatarsal articular surface, in $\mathrm{cm}$; internal carcass length (ICL), distance between the midpoints of the cranial edge of the pubis and the cranial edge of the first rib, on its midpoint, in $\mathrm{cm}$; external carcass length (ECL), distance between the base of the tail and the base of the neck, in $\mathrm{cm}$; height at the rump (HR), maximum width between the trochanters of both femurs, in $\mathrm{cm}$; rump perimeter (RP), perimeter of this anatomical region, having the trochanters of both femurs as reference, in $\mathrm{cm}$; and depth of the chest (DC), maximum distance between the sternum and the back of the carcass, in $\mathrm{cm}$. The indices of carcass compactness, defined by the CCW/ICL quotient, $\mathrm{kg} / \mathrm{cm}$; and leg compactness, given by RP/LL, were also calculated (Reis et al., 2001).

A cross-section cut was made between the 12th and 13th ribs of the left half carcass, and the perimeter of muscle Longissimus dorsi was measured by tracing the outlines on tracing papers. Subsequently, the loin eye area (LEA) was determined by leaf area meter LI-3100 AREA METER. Still in the Longissimus dorsi, with the use of a pachymeter, the back fat thickness (BFT) was measured at the point equivalent to $2 / 3$ of the longitudinal section of the muscle. In the same muscle, the color was determined with the use of Mini SCan 45/0LAV colorimeter model 45/0, with a D65 illuminant source and an angle of $10^{\circ}$. The evaluation system utilized was CIELab, in which $\mathrm{L}^{*}$ corresponds to the level of brightness; $a^{*}$, to the redness; and $b^{*}$ to the yellowness (Commision Internacionale I'Éclairage, 1931). The texture was evaluated by visual assessment of the size of the fiber bundle, utilizing a subjective scale with indices from 1 (very thick) to 5 (very thin), according to Müller (1987).

The data were analyzed by variance and regression analysis. The models were chosen based on the significance of the regression coefficients utilizing the $\mathrm{F}$ test, adopting $5 \%$ of probability in the coefficient of determination and in the variable studied. Pearson's coefficient correlations were estimated. To compare the means of variables LEA and BFT due to this method, $F$ test at $5 \%$ probability was performed through Sistema de Análises Estatísticas e 
Genéticas - SAEG (UFV/CPD, 1997), in conformity with the following model: $\mathrm{Y}_{\mathrm{ij}}=\mu+$ $\mathrm{C}_{\mathrm{i}}+\mathrm{e}_{\mathrm{ij}}$, in which C: level of concentrate $(20,40$, 60 and $80 \%$ ), and e: random error associated with observation.

\section{RESULTS AND DISCUSSION}

Live weight, live weight at slaughter, empty body weight, warm carcass yield and cold carcass weight presented positive linear effect due to the increase in the levels of concentrate in the diet (Table 1), which can be attributed to the fact that diets were not formulated with the same amount of energy and protein, and supplied nutrients above the requirements for maintenance, promoting different weight at slaughter and different gains for the different treatments $(145,171,206$ and $243 \mathrm{~g} /$ day for the levels of 20,40, 60 and $80 \%$ concentrate, respectively).

Table 1. Means, coefficients of variation (CV), regression equations and determination coefficients $\left(\mathrm{R}^{2}\right)$ for the variables analyzed according to the increasing levels of concentrate in the diets

\begin{tabular}{|c|c|c|c|c|c|c|c|}
\hline \multirow[t]{2}{*}{ Variables } & \multicolumn{4}{|c|}{ Level of concentrate } & \multirow[t]{2}{*}{$\mathrm{CV}$} & \multirow[t]{2}{*}{ Regression } & \multirow[t]{2}{*}{$\mathrm{R}^{2}$} \\
\hline & 20 & 40 & 60 & 80 & & & \\
\hline LW (kg) & 39.46 & 42.31 & 46.05 & 50.30 & 8.48 & $Y=35.4630+0.181294 C^{*}$ & 0.99 \\
\hline LWS (kg) & 36.23 & 39.77 & 43.61 & 47.86 & 9.23 & $Y=32.1518+0.197970 C^{*}$ & 0.99 \\
\hline FL $(\%)$ & 8.93 & 6.45 & 5.66 & 5.15 & 30.50 & $\mathrm{Y}=9.58162-0.0606551 \mathrm{C}^{*}$ & 0.87 \\
\hline CGIT (kg) & 7.18 & 6.26 & 5.99 & 5.90 & 13.34 & $\mathrm{Y}=7.34516-0.0201189 \mathrm{C}^{*}$ & 0.82 \\
\hline $\mathrm{EBW}(\mathrm{kg})$ & 28.58 & 33.63 & 38.01 & 41.83 & 9.48 & $Y=24.7794+0.217072 C^{*}$ & 0.99 \\
\hline WCW (kg) & 15.83 & 19.03 & 22.00 & 24.93 & 9.13 & $Y=12.8833+0.151333 C^{*}$ & 0.99 \\
\hline $\mathrm{CCW}(\mathrm{kg})$ & 15.67 & 18.78 & 21.72 & 24.63 & 9.17 & $\mathrm{Y}=12.7417+0.167 \mathrm{C}^{*}$ & 0.99 \\
\hline $\mathrm{CL}(\%)$ & 1.06 & 1.30 & 1.28 & 1.22 & 49.81 & $\mathrm{Y}=1.214337^{\mathrm{ns}}$ & - \\
\hline WCY $(\%)$ & 43.72 & 47.88 & 50.41 & 52.17 & 3.39 & $Y=41.5806+0.139302 C^{*}$ & 0.96 \\
\hline $\mathrm{CCY}(\%)$ & 43.27 & 47.25 & 49.77 & 51.54 & 3.48 & $Y=41.1232+0.136631 C^{*}$ & 0.97 \\
\hline $\mathrm{TY}(\%)$ & 55.11 & 56.56 & 58.49 & 59.70 & 3.50 & $Y=53.8227+0.0753648 C^{*}$ & 0.99 \\
\hline
\end{tabular}

C: Level of concentrate; ns - not significant; * significant at $5 \%$ probability. LW: live weight; LWS: live weight at slaughter; FL: fasting loss; CGIT: content of the gastrointestinal tract; EBW: empty body weight; WCW: warm carcass weight; CCW: cold carcass weight; CL: cooling loss; WCY: warm carcass yield; CCY: cold carcass yield; TY: true yield.

Both LW and LWS were highly correlated with WCW and CCW (Table 2). Consequently, the greater the LWS, the greater the number of edible cuts contained in WCW and $\mathrm{CCW}$, which are, in turn, highly correlated with carcass compactness (CarcC).

Corroborating these results, Gonzaga Neto et al. (2006), evaluating the effect from the level of concentrate $(30,45$ and $60 \%)$ in diets supplied to uncastrated Morada Nova lambs, also verified that LW and LWS were positively influenced by the increasing levels of concentrate, because diets presented different protein and energy compositions.

Fasting loss (FL) (Table 1), expressed in percentage, reduced linearly with the increase in the levels of concentrate, as well as the content in the gastrointestinal tract (CGIT). Such facts indicate that the animals which receive diets with a greater proportion of roughage have a longer retention time in the rumen and in the gastrointestinal tract, having heavier CGIT weight as a consequence, in contrast to the lighter weight of the animals subjected to the more elevated levels of concentrate in the diet.

The increase in the level of concentrate did not change cooling loss (CL), due to the high deposition of subcutaneous fat in the carcass, whereby the lowest value of backfat thickness (BFT) was $2.24 \mathrm{~mm}$ (Table 4), which would have already been enough to avoid cooling losses, once the muscle fibers of sheep meat are thin. Thus, the backfat contributed to obtain a low CL, which averages only $1.21 \%$. Besides, the lack of effect for CL might have been a result from the high coefficient of variation presented by this variable. 
Quantitative and qualitative...

Table 2. Pearson correlation between the analyzed variables of feedlot ewes subjected to increasing levels of concentrate in the diets

\begin{tabular}{|c|c|c|c|c|c|c|c|c|c|c|c|c|c|c|c|c|}
\hline & LW & LWS & WCW & $\mathrm{CCW}$ & WCY & CCY & HW & HR & BL & ECL & ICL & RP & RW & DC & LL & CarcC \\
\hline \multicolumn{17}{|l|}{ LW } \\
\hline \multirow{2}{*}{ LWS } & 0.99 & & & & & & & & & & & & & & & \\
\hline & $\begin{array}{l}* * \\
0.94\end{array}$ & & & & & & & & & & & & & & & \\
\hline \multirow[t]{2}{*}{ WCW } & $* *$ & ** & & & & & & & & & & & & & & \\
\hline & $\begin{array}{c}0.94 \\
* *\end{array}$ & $\begin{array}{c}0.96 \\
* *\end{array}$ & $\begin{array}{c}0.99 \\
* *\end{array}$ & & & & & & & & & & & & & \\
\hline $\mathrm{CCW}$ & 0.61 & 0.64 & 0.84 & 0.83 & & & & & & & & & & & & \\
\hline \multirow[t]{2}{*}{ WCY } & $* *$ & $* *$ & $* *$ & $* *$ & & & & & & & & & & & & \\
\hline & $\begin{array}{c}0.61 \\
* *\end{array}$ & $\begin{array}{c}0.64 \\
* *\end{array}$ & $\begin{array}{c}0.83 \\
* *\end{array}$ & $\begin{array}{c}0.83 \\
* *\end{array}$ & $\begin{array}{c}0.99 \\
* *\end{array}$ & & & & & & & & & & & \\
\hline $\mathrm{CCY}$ & $\begin{array}{c}0.66 \\
* *\end{array}$ & $\begin{array}{c}0.69 \\
* *\end{array}$ & $\begin{array}{c}0.74 \\
* *\end{array}$ & $\begin{array}{c}0.73 \\
* *\end{array}$ & $\begin{array}{c}0.66 \\
* *\end{array}$ & $\begin{array}{c}0.65 \\
* *\end{array}$ & & & & & & & & & & \\
\hline HW & 0.57 & 0.57 & 0.60 & 0.59 & 0.49 & 0.47 & 0.86 & & & & & & & & & \\
\hline \multirow[t]{2}{*}{ HR } & $* *$ & $* *$ & $* *$ & $* *$ & $* *$ & * & $* *$ & & & & & & & & & \\
\hline & $\begin{array}{c}0.38 \\
*\end{array}$ & $\begin{array}{c}0.42 \\
*\end{array}$ & $\begin{array}{c}0.26 \\
\text { ns }\end{array}$ & $\begin{array}{c}0.26 \\
\text { ns }\end{array}$ & $\begin{array}{c}-0.09 \\
\mathrm{~ns}\end{array}$ & $\begin{array}{c}-0.11 \\
\mathrm{~ns}\end{array}$ & $\begin{array}{c}0.29 \\
\text { ns }\end{array}$ & $\begin{array}{c}0.30 \\
\mathrm{~ns}\end{array}$ & & & & & & & & \\
\hline BL & & -0.07 & -0.12 & -0.12 & -0.16 & -0.17 & -0.02 & -0.06 & 0.27 & & & & & & & \\
\hline \multirow[t]{2}{*}{ ECL } & $-0.10 \mathrm{~ns}$ & $\mathrm{~ns}$ & $\mathrm{~ns}$ & $\mathrm{~ns}$ & ns & $\mathrm{ns}$ & $\mathrm{ns}$ & $\mathrm{ns}$ & $\mathrm{ns}$ & & & & & & & \\
\hline & & 0.48 & 0.42 & 0.42 & 0.20 & 0.20 & 0.33 & 0.25 & 0.50 & 0.32 & & & & & & \\
\hline \multirow[t]{2}{*}{ ICL } & $0.44 *$ & $* *$ & $*$ & $*$ & $\mathrm{~ns}$ & $\mathrm{~ns}$ & $\mathrm{~ns}$ & $\mathrm{~ns}$ & $* *$ & $\mathrm{~ns}$ & & & & & & \\
\hline & 0.86 & 0.86 & 0.92 & 0.92 & 0.82 & 0.80 & 0.66 & 0.49 & 0.14 & -0.25 & & & & & & \\
\hline \multirow[t]{2}{*}{$\mathrm{RP}$} & $* *$ & $* *$ & $* *$ & $* *$ & $* *$ & $* *$ & $* *$ & $* *$ & $\mathrm{~ns}$ & ns & $0.25 \mathrm{~ns}$ & & & & & \\
\hline & $\begin{array}{c}0.84 \\
* *\end{array}$ & $\begin{array}{c}0.85 \\
* *\end{array}$ & $\begin{array}{c}0.86 \\
* *\end{array}$ & $\begin{array}{c}0.85 \\
* *\end{array}$ & $\begin{array}{c}0.67 \\
* *\end{array}$ & $\begin{array}{c}0.66 \\
* *\end{array}$ & $\begin{array}{c}0.67 \\
* *\end{array}$ & $\begin{array}{c}0.52 \\
* *\end{array}$ & 0.22 & -0.22 & $027 \mathrm{~ns}$ & $\begin{array}{c}0.92 \\
* *\end{array}$ & & & & \\
\hline RW & 0.75 & 0.78 & 0.78 & 0.78 & 0.59 & 0.60 & & 0.46 & $\begin{array}{c}\mathrm{ns} \\
0.49\end{array}$ & $\begin{array}{c}\text { ns } \\
-0.08\end{array}$ & $0.2 / \mathrm{ns}$ & 0.60 & 0.55 & & & \\
\hline DC & $* *$ & $* *$ & $* *$ & $* *$ & $* *$ & $* *$ & $0.58 * *$ & $*$ & $* *$ & ns & $0.44 *$ & $* *$ & $* *$ & & & \\
\hline \multirow[t]{2}{*}{ LL } & $\begin{array}{c}-0.14 \\
\text { ns }\end{array}$ & $\begin{array}{c}-0.07 \\
\mathrm{~ns}\end{array}$ & $\begin{array}{c}-0.12 \\
\mathrm{~ns}\end{array}$ & $\begin{array}{c}-0.12 \\
\mathrm{~ns}\end{array}$ & $\begin{array}{c}-0.20 \\
\text { ns }\end{array}$ & $\begin{array}{c}-0.19 \\
\text { ns }\end{array}$ & $\begin{array}{c}0.10 \\
\mathrm{~ns}\end{array}$ & $\begin{array}{c}0.06 \\
\text { ns }\end{array}$ & $\begin{array}{c}0.40 \\
*\end{array}$ & $\begin{array}{c}0.33 \\
\mathrm{~ns}\end{array}$ & $\begin{array}{c}0.39 \\
*\end{array}$ & $\begin{array}{c}-0.25 \\
\mathrm{~ns}\end{array}$ & $\begin{array}{c}-0.16 \\
\mathrm{~ns}\end{array}$ & $\begin{array}{c}0.02 \\
\text { ns }\end{array}$ & & \\
\hline & 0.89 & 0.90 & 0.95 & 0.96 & 0.81 & 0.82 & 0.66 & 0.55 & 0.14 & -0.40 & 0.30 & 0.91 & 0.84 & 0.74 & -0.21 & \\
\hline \multirow[t]{2}{*}{ CarcC } & $* *$ & $* *$ & $* *$ & $* *$ & $* *$ & $* *$ & $* *$ & $*$ & $\mathrm{~ns}$ & $*$ & $\mathrm{~ns}$ & $* *$ & $* *$ & $* *$ & ns & \\
\hline & 0.65 & 0.61 & 0.65 & 0.65 & 0.58 & 0.57 & 0.38 & 0.31 & -0.12 & -0.37 & -0.07 & & 0.77 & 0.36 & -0.75 & 0.69 \\
\hline $\operatorname{Leg} C$ & $* *$ & $* *$ & $* *$ & $* *$ & $* *$ & $* *$ & $*$ & ns & $\mathrm{ns}$ & $*$ & ns & $0.78 * *$ & $* *$ & $*$ & $* *$ & $* *$ \\
\hline
\end{tabular}

** $\mathrm{P}<0.01$; $* \mathrm{P}<0.05$; ns: not significant. LW: live weight; LWS: live weight at slaughter; WCW: warm carcass weight; CCW: cold carcass weight; WCY: warm carcass yield; CCY: cold carcass yield; HW: height at the withers; HR: height at the rump; BL: body length; ECL: external carcass length; ICL: internal carcass length; RP: rump perimeter; RW: rump width; DC: depth of the chest; LL: length of the leg; CarcC: carcass compactness; LegC: leg compactness.

Ezik et al. (2013) when comparing lambs finished on pasture and feedlot also found no differences in CL and likewise assigned this finding to the fact that animals fed exclusively on fodder also possessed adequate fat cover, giving good protection to the cooling process.

The warm carcass (WCY), cold carcass (CCY) and true yields (TY) presented positive linear effect with the increase of concentrate in the diet. Live weight at slaughter showed medium to high correlation with WCY and CCY, demonstrating that greater warm and cold carcass yields can be obtained with increase in LWS.

According to Carvalho et al. (2005), the reduction in CGIT is an important factor from the commercial point of view, because it is associated with better carcass yield, and consequently, it can promote greater amount of edible material to the consumer. Therefore, part of the increase in WCY, CCY and TY can also be explained by the decrease in CGIT weight resulting from the increase in the levels of concentrate and, consequently, decrease in the fiber ingestion and increase in the degradation rate and passage of the feed.

The in vivo body measures obtained for height at the withers (HW) and at the rump (HR) presented a positive linear effect, but body length (BL) did not present an effect from the level of concentrate in the diet, which mean value was $73.37 \mathrm{~cm}$ (Table 3). Furthermore, one can observe that for each $1 \%$ of concentrate added to 
the diet, there was increase of $0.18 \mathrm{~cm}$ for $\mathrm{HW}$ and $0.16 \mathrm{~cm}$ for $\mathrm{HR}$.

Associating these results with the correlation coefficient values presented in Table 2, we can observe that HW (0.69), HR (0.57) and BL $(0.42)$ have medium to low correlation with
LWS, and that HW and HR have from medium to high correlation, which value was 0.86 . However, neither HW nor HR presented significant correlation with BL, so this can be a possible explanation for the absence of effect from the increase in the levels of concentrate in relation to $\mathrm{BL}$.

Table 3. Means, coefficients of variation $(\mathrm{CV})$, regression equations and determination coefficients $\left(\mathrm{R}^{2}\right)$ for the in vivo and carcass body measurements according to the increasing levels of concentrate in the diets

\begin{tabular}{|c|c|c|c|c|c|c|c|}
\hline \multirow[t]{2}{*}{ Variables } & \multicolumn{4}{|c|}{ Levels of concentrate } & \multirow[t]{2}{*}{$\mathrm{CV}$} & \multirow[t]{2}{*}{ Regression } & \multirow[t]{2}{*}{$\mathrm{R}^{2}$} \\
\hline & 20 & 40 & 60 & 80 & & & \\
\hline \multicolumn{8}{|c|}{ In vivo body measurements } \\
\hline $\mathrm{HW}(\mathrm{cm})$ & 59.83 & 65.00 & 68.50 & 70.50 & 4.82 & $Y=57.0833+0.17750 C^{*}$ & 0.96 \\
\hline $\mathrm{HR}(\mathrm{cm})$ & 65.58 & 70.50 & 71.42 & 75.92 & 6.45 & $Y=62.8750+0.159583 C^{*}$ & 0.95 \\
\hline $\mathrm{BL}(\mathrm{cm})$ & 72.45 & 73.92 & 74.33 & 72.80 & 7.37 & $\mathrm{Y}=73.37500^{\mathrm{ns}}$ & - \\
\hline \multicolumn{8}{|c|}{ Measurements on the carcass } \\
\hline ECL $(\mathrm{cm})$ & 71.03 & 73.33 & 73.87 & 70.13 & 6.51 & $\mathrm{Y}=72.09167^{\mathrm{ns}}$ & - \\
\hline $\mathrm{ICL}(\mathrm{cm})$ & 60.57 & 61.33 & 62.13 & 63.08 & 4.34 & $\mathrm{Y}=61.77917^{\mathrm{ns}}$ & - \\
\hline $\mathrm{RP}(\mathrm{cm})$ & 59.48 & 62.65 & 65.25 & 67.23 & 3.74 & $\mathrm{Y}=57.1917+0.129250 \mathrm{C}^{*}$ & 0.99 \\
\hline $\mathrm{RW}(\mathrm{cm})$ & 20.82 & 21.47 & 22.33 & 22.97 & 3.44 & $Y=20.0667+0.0365833 C^{*}$ & 0.99 \\
\hline $\mathrm{DC}(\mathrm{cm})$ & 24.72 & 26.32 & 27.03 & 27.68 & 5.64 & $Y=24.0333+0.0480833 C^{*}$ & 0.95 \\
\hline $\mathrm{LL}(\mathrm{cm})$ & 31.22 & 31.40 & 31.05 & 30.62 & 5.05 & $\mathrm{Y}=31.07083^{\mathrm{ns}}$ & - \\
\hline $\operatorname{CarcC}(\mathrm{kg} / \mathrm{cm})$ & 0.22 & 0.26 & 0.29 & 0.35 & 12.16 & $Y=0.173987+0.00215369 C^{*}$ & 0.99 \\
\hline LegC & 0.67 & 0.69 & 0.72 & 0.75 & 6.14 & $\mathrm{Y}=0.636786+0.00139431 \mathrm{C}^{*}$ & 0.98 \\
\hline
\end{tabular}

Therefore, in general, body measurements are more influenced by genetics and age than by the diet supplied, for each breed has a body structure according to the genotype (Cadavez, 2009).

It can be observed that external carcass length (ECL), internal carcass length (ICL) and length of the leg (LL) also did not present an effect from the gradual increase of concentrate in the diet (Table 3). However, rump perimeter (RP), rump width (RW) and depth of the chest (DC) increased linearly according to the levels of concentrate in the diet. Because LWS was the first response obtained with increase in the levels of concentrate and analyzing the correlation coefficients of the carcass measurements (Table 2), we can observe that ECL and LL were not significantly correlated with LWS, and ICL had from medium to low correlation with it (0.48). However, RP (0.86), RW (0.85) and DC (0.78) presented from medium to high correlation with LWS.
Carcass compactness (CarcC) and leg compactness (LegC) (Table 3) also increased linearly according to the level of concentrate in the diet, and for every $1 \%$ of concentrate added, about $0.00215 \mathrm{~kg} / \mathrm{cm}$ was increased in the $\mathrm{CarcC}$, with constant ICL and CCW in a linear increase, which ensured greater $\mathrm{kg} / \mathrm{cm}$ of carcass. Likewise, LegC rose 0.00139 at every $1 \%$ of concentrate added to the diet, which was a result of the increase in RW, which presented increasing linear effect in relation to LL, which kept constant at all the levels of concentrate.

Both CarcC and LegC were negatively correlated with ICL (Table 2), showing that carcasses with greater internal length can result in lower compactness values. Besides, RP and RW were highly correlated with CarcC and LegC, because carcasses with greater RP and RW can provide more carcass and leg compactness. Therefore, the greater the RP, the lower the LegC. 
Evaluating the effect from different slaughter weights on the carcass measurements, Issakowicz et al. (2013) found $0.361 \mathrm{~kg} / \mathrm{cm}$ and $0.316 \mathrm{~kg} / \mathrm{cm}$ of CarcC, with the highest values for the greatest concentrate proportion, similar to the values obtained in this study. Overall, when correlating the in vivo body measurements with the measurements obtained on the carcass, we can verify that the correlations varied from medium to low, demonstrating that in vivo body measurements cannot be utilized as the sole parameter for prediction of the carcass measurements.

Both the loin eye area measured on the carcass (LEAc) and with ultrasound (LEAu) presented positive linear effect, confirming that increasing levels of concentrate can promote greater growth of the muscle area (Table 4).

Table 4. Means, coefficient of variation $(\mathrm{CV})$, regression equations and determination coefficients $\left(\mathrm{R}^{2}\right)$ for the measurements of loin eye area measured on the carcass (LEAc) and via ultrasound (LEAu), in $\mathrm{cm}^{2}$ and back fat thickness measured on the carcass (BFTc) and via ultrasound (BFTu), in mm, according to the increasing levels of concentrate in the diets

\begin{tabular}{|c|c|c|c|c|c|c|c|}
\hline \multirow[t]{2}{*}{ Variables } & \multicolumn{4}{|c|}{ Level of concentrate } & \multirow[t]{2}{*}{$\mathrm{CV}$} & \multirow[t]{2}{*}{ Regression } & \multirow[t]{2}{*}{$\mathrm{R}^{2}$} \\
\hline & 20 & 40 & 60 & 80 & & & \\
\hline \multicolumn{8}{|c|}{ Loin eye area } \\
\hline LEAc & $8.64 \mathrm{a}$ & $12.11 \mathrm{a}$ & $11.79 \mathrm{a}$ & $13.24 \mathrm{a}$ & 13.82 & $\mathrm{Y}=8.07833+0.0673500 \mathrm{C}^{*}$ & 0.78 \\
\hline LEAu & $9.61 \mathrm{a}$ & $11.22 \mathrm{a}$ & $12.12 \mathrm{a}$ & $12.99 \mathrm{a}$ & 12.26 & $\mathrm{Y}=8.72250+0.0552583 \mathrm{C} *$ & 0.97 \\
\hline $\mathrm{CV}$ & 16.88 & 13.70 & 11.30 & 10.98 & & & \\
\hline $\mathrm{P}$ & 0.5240 & 0.2540 & 0.2504 & 0.4250 & & & \\
\hline \multicolumn{8}{|c|}{ Back fat thickness } \\
\hline BFTc & $2.24 \mathrm{a}$ & $3.78 \mathrm{a}$ & $5.46 \mathrm{a}$ & $7.41 \mathrm{a}$ & 45.78 & $Y=0.42500+0.0859917 C^{*}$ & 0.99 \\
\hline BFTu & $1.97 \mathrm{a}$ & $2.25 \mathrm{~b}$ & $3.10 \mathrm{~b}$ & $4.25 \mathrm{~b}$ & 37.39 & $Y=0.966667+0.385000 C^{*}$ & 0.94 \\
\hline $\mathrm{CV}$ & 45.84 & 55.65 & 43.47 & 36.96 & & & \\
\hline $\mathrm{P}$ & 0.40527 & 0.04594 & 0.04244 & 0.02928 & & & \\
\hline
\end{tabular}

1 Means followed by the same letter in the same column do not differ by the F test (P>0.05); C: Level of concentrate; ns - not significant; * significant at $5 \%$ probability.

The bac kfat thickness measured on the carcass (BFTc) and that obtained by ultrasound (BFTu) also presented positive linear effect from the levels of concentrate (Table 4), i.e., the greater level of concentrate in the diet can promote greater deposition of subcutaneous fat.

According to Kosloski (2009), the increase in the level of concentrate in the diet probably brought about an alteration in the level of volatile fatty acids (VFA), causing an increase of propionate and decrease of acetate, which might have contributed to the increase in the energy available for the visceral metabolism, thus favoring greater deposition of subcutaneous fat and greater production of muscle mass as a result from the economy of energy in the oxidation of neo-glucogenic amino acids (Riegel, 2012).

Issakowicz et al. (2013) supplying different levels of concentrate $(60$ and $80 \%$ of concentrate) in the diet of feedlot lambs of the Texel breed, observed that the raise in the level of concentrate did not increase LEA linearly, with values of 13.1 and $12.8 \mathrm{~cm}^{2}$. Comparing the values, it can be observed that they are similar to those presented by the ewes of undefined breed in this study.

Abdullah and Qudsieh (2008) observed that the amount of back fat rose gradually with increase in weight, and the carcass quality was also associated to slaughter body weight. These results corroborate the concept that the increasing concentrate level and energy supply improved the fat deposition. Furthermore, females are physiologically mature earlier than males and are consequently more prone to deposit fat in the carcass, which explains the high deposition of subcutaneous fat in the ewes of the present study.

Comparing LEAc with LEAu, we can observe that the values obtained with the two techniques (ultrasound examination and on the carcass) were similar, since there was no significant difference between the two techniques, demonstrating the efficiency of ultrasound to estimate LEA. This 
information is extremely important, because the use of the ultrasound examination technique for the measurement of LEA can help in the determination of the optimal slaughter weight, according to the fat cover degree measured by BFT.

However, analyzing the BFTc and BFTu, it was observed that the BFT measured by ultrasound underestimated the BFT measured on the carcass. This result makes it possible to infer that the chances of error in the BFT measurements assessed by ultrasound are greater, and that other factors are interfering in this measurement, such as the site of measurement.

Analyzing the correlation of the variables studied (Table 5), we can initially observe that the LEA and BFT measured on the carcass and with ultrasound examination were highly correlated with LW and LWS, and that LEAc was highly correlated with LEAu ( $\mathrm{r}=0.81)$, as well as BFTc and BFTu $(\mathrm{r}=0.85)$.

Table 5. Pearson correlation between the variables live weight (LW), live weight at slaughter (LWS), loin eye area (LEA) and back fat thickness (BFT) measured on the carcass (c) and by ultrasound examination (u) of feedlot ewes subjected to increasing levels of concentrate in the diets

\begin{tabular}{cccccc}
\hline & LW & LWS & LEAc & LEAu & BFTc \\
\hline LEAc & $0.70^{* *}$ & $0.73^{* *}$ & & & \\
LEAu & $0.76^{* *}$ & $0.77^{* *}$ & $0.81^{* *}$ & & \\
BFTc & $0.77^{* *}$ & $0.78^{* *}$ & $0.52^{* *}$ & $0.52^{* *}$ & \\
BFTu & $0.70^{* *}$ & $0.68^{* *}$ & $0.43^{*}$ & $0.53^{* *}$ & $0.85^{* *}$ \\
\hline
\end{tabular}

$* * \mathrm{P}<0.01 ; * \mathrm{P}<0.05$

However, Ítavo et al. (2009), evaluating the loin eye area and back fat thickness by ultrasound and directly on the carcass of feedlot-finished lambs with diets containing $50 \%$ concentrate, verified that the ultrasound underestimated LEA $\left(9.08 \mathrm{~cm}^{2}\right.$ for ultrasound and $12.14 \mathrm{~cm}^{2}$ on the carcass). However, the correlation of the LEA measured by the two techniques (ultrasound and carcass) was considered from medium to high, which value was $r=0.8597$, which demonstrates that although the ultrasound technique underestimated the LEA, the latter can be utilized for the prediction of the ideal moment for slaughter. Likewise, Ítavo et al. (2009), evaluating BFT, verified that the ultrasound overestimated BFT (2.69 mm for ultrasound and $2.42 \mathrm{~mm}$ on the carcass) in male lambs, which contrasts the results of this study. It is worth stressing that the $\mathrm{CV}$ obtained by those authors was lower $(18.65 \%)$ than the CV in this study. Besides, Ítavo et al. (2009) indicated that the low correlation (0.3926) between ultrasoundmeasured BFT and BFT measured on the carcass demonstrated that the ultrasound examination was not an effective tool for the determination of the moment pre-slaughter fat cover of the animals.

Regarding meat color (Table 6), it can be observed that neither component $L^{*}$ nor $b^{*}$ suffered any alterations with the inclusion of concentrate, as opposing to component $\mathrm{a}^{*}$, which increased linearly with the inclusion of concentrate. Therefore, meat always showed the same brightness in all the treatments, but always redder.

Table 6. Means, coefficient of variation $(\mathrm{CV})$, regression equations and determination coefficients $\left(\mathrm{R}^{2}\right)$ for brightness and color of the muscle Longissimus dorsi ( $\mathrm{L}^{*}, \mathrm{a}^{*}$ and $\mathrm{b}^{*}$ ) and meat texture, according to the increasing levels of concentrate in the diets

\begin{tabular}{|c|c|c|c|c|c|c|c|}
\hline \multirow[t]{2}{*}{ Variables } & \multicolumn{4}{|c|}{ Level of concentrate } & \multirow[t]{2}{*}{$\mathrm{CV}$} & \multirow[t]{2}{*}{ Regression } & \multirow[t]{2}{*}{$\mathrm{R}^{2}$} \\
\hline & 20 & 40 & 60 & 80 & & & \\
\hline $\mathrm{L}^{*}$ & 41.34 & 39.19 & 39.39 & 41.98 & 8.18 & $\mathrm{Y}=40.47542^{\mathrm{ns}}$ & - \\
\hline$a^{*}$ & 19.50 & 20.60 & 21.73 & 21.65 & 6.78 & $\mathrm{Y}=18.9808+0.037725 \mathrm{C}^{*}$ & 0.87 \\
\hline$b^{*}$ & 11.70 & 11.36 & 12.05 & 12.90 & 9.11 & $\mathrm{Y}=12.00208^{\mathrm{ns}}$ & - \\
\hline Texture & 4.00 & 4.33 & 4.33 & 4.5 & 14.89 & $\mathrm{Y}=4.29167^{\mathrm{ns}}$ & - \\
\hline
\end{tabular}


Bressan et al. (2001), evaluating the effect of slaughter weight on the meat color of uncastrated Santa Inês and Bergamácia lambs, observed that $\mathrm{L}^{*}$ decreased from 42.29 to 32.46 , a* increased from 10.39 to 13.89 and $b^{*}$ increased from 6.73 to 8.15 , with increase in slaughter weight from 15 to $45 \mathrm{~kg}$ of $\mathrm{LW}$. This indicated that the meat from the lambs presented a darker red color as the slaughter weight increased. Moreover, in this study the brightness remained constant and the values of $\mathrm{a}^{*}$ and $\mathrm{b}^{*}$ were superior when compared with the values mentioned by the authors.

According to Majdoub-Mathlouthi et al. (2013) the darker color is related to the fat content in the meat and not exactly to sex, since higher fat content may have greater reflectance, thus increasing the values of $\mathrm{L}^{*}$ and brightening the meat. The inclusion of concentrate did not alter the texture of meat from feedlot ewes, presenting a mean value of 4.29. This value is considered fine texture, so it is a good characteristic, once, according to Gularte et al. (2000), it indicates a smaller diameter of the muscle fibers, gives better appearance and implies that the meat is from a young animal, which is consequently associated with greater tenderness. These results make it possible to infer that the feedlot ewes from this assay presented good meat quality as to the visual parameters (color and brightness) and softness in the texture. It is possible that the early age of animals contributed to these results.

\section{CONCLUSIONS}

The increase in the use of concentrate promotes heavier carcasses with greater yield and fat cover. Not all in vivo body measurements present high correlation with the carcass measurements, and they should be associated with other variables such as LEA and BFT. The ultrasound examination can be utilized as a method of predicting the loin eye area in vivo. The use of concentrate improves the meat quality, both as to its color and appearance.

\section{REFERENCES}

ABDULLAH, Y.A.; QUDSIEH, R.I. Carcass characteristics of Awassi ram lambs slaughtered at different weights. Livestock Sci., v.117, p.165$175,2008$.

BRESSAN, M.C.; PRADO, O.V.; PÉREZ, J.R.O. et al. Efeito do peso ao abate de cordeiros santa inês e bergamácia sobre as características físico-químicas da carne. Cienc. Tecnol. Aliment., v.21, p.293-303, 2001.

CADAVEZ, V.A.P. Prediction of lean meat proportion of lamb carcasses. Arch. Zootech., v.12, p.46-58, 2009.

CARDOSO, M.T.M. Desempenho e características de carcaça de ovinos da raça Santa Inês e seus cruzamentos em sistema intensivo de produção. 2008. 117f. Dissertação (Mestrado em Ciências Animais) - Faculdade de Agronomia e Medicina Veterinária, Universidade de Brasília, Brasília.

CARVALHO, S.; VERGUEIRO, A.; KIELING, R. et al. Avaliação da suplementação concentrada em pastagem de Tifton-85 sobre os componentes não carcaça de cordeiros. Cienc.Rural, v.35, p.435-439, 2005.

COMMISSION INTERNATIONALE DE L'ÉCLAIRAGE. Proceedings of the eight session. Cambridge, Inglaterra: Bureau Central de la Commission Internationale de L'Éclairage, $1931.326 \mathrm{p}$.

EZIK, B.; DEMIREL, G.; YILMAZ, A. et al. Slaughter characteristics, carcass quality and fatty acid composition of lambs under four different production systems. Small Rum. Res., v.114, p.26-34, 2013.

GONZAGA NETO, S.; SILVA SOBRINHO, A.G.; ZEOLA, N.M.B.L. et al. Características quantitativas da carcaça de cordeiros deslanados Morada Nova em função da relação volumoso:concentrado na dieta. Rev. Bras. Zootec., v.35, p.1487-1495, 2006.

GULARTE, M.A.; TREPTOW, R.O.; POUEY, J.L.; OSÓRIO, J.C. Idade e sexo na maciez da carne de ovinos da raça Corriedale. Cienc. Rural, v.30, p.485-488, 2000. 
ISSAKOWICZ, J.; BUENO, M.S.; SAMPAIO, A.C.K.; DUARTE, K.M.R. Effect of concentrate level and live yeast (Saccharomyces cerevisiae) supplementation on Texel lamb performance and carcass characteristics. Livestock Sci, v.155, p.44-52, 2013.

ÍTAVO, C.C.B.F.; MORAIS, M.G.; COSTA, C. et al. Características de carcaça, componentes corporais e rendimento de cortes de cordeiros confinados recebendo dieta com própolis ou monensina sódica. Rev. Bras. Zootec., v.38, p.898-905, 2009.

KOZLOSKI, G.V. Bioquímica dos ruminantes. 2.ed. Santa Maria: Ed. da UFSM, 2009. 98p.

MAJDOUB-MATHLOUTHI, L.; SAID, B.; SAY, A. et al. Effect of concentrate level and slaughter body weight on growth performances, carcass traits and meat quality of Barbarine lambs fed oat hay based diet. Meat Science, v.93, p.557-563, 2013.

McMANUS, C.; PAIM, T.P.; LOUVANDINI, H. et al. Avaliação ultrasonográfica da qualidade de carcaça de ovinos santa Inês. Cien. Anim. Bras., v.14, p.8-16, 2013.

MÜLLER, L. Normas para avaliação de carcaças e concurso de carcaças de novilhos. Santa Maria: Imprensa Universitária, 1987. 13p.
NUTRIENT requirements of small ruminants. 1.ed. Washington : National Academy of Science, 2007. 362p.

PINHEIRO, R.S.B.; JORGE, A.M.; MOURÃO, R.C. et al. Qualidade da carne de cordeiros confinados recebendo diferentes relações de volumoso:concentrado na dieta. Cienc. Tecnol. Aliment., v.29, p.407-411, 2009.

REIS, W.; JOBIM, C.C.; MACEDO, F.A.F. et al. Características da carcaça de cordeiros alimentados com dietas contendo grãos de milho conservados em diferentes formas. Rev. Bras. Zootec., v.30, p.1308-1315, 2001.

RIEGEL, R.E. Bioquímica. 5.ed. São Leopoldo: Unisinos, 2012. 197p.

UFV - UNIVERSIDADE FEDERAL DE VIÇOSA. Manual de utilização do Programa SAEG (Sistema para Análises Estatísticas $e$ Genéticas). Viçosa: Universidade Federal de Viçosa, 1997. 59p.

YOKOO, M.J.I.; WERNECK, J.N.; PEREIRA, M.C. et al. Correlações genéticas entre escores visuais e características de carcaça medidas por ultrasson em bovinos de corte. Pesq. Agropec. Bras., v.44, p.197-202, fev. 2009. 